\title{
ANALISIS STRUKTUR DAN STATUS EKOSISTIM MANGROVE DI PERAIRAN TIMUR KABUPATEN BIAK NUMFOR
}

\author{
Bernhard Katiandagho \\ Staf Pengajar Akademi Perikanan Kamasan Biak-Papua,e-mail: katiandagho_bernhard@yahoo.com
}

\begin{abstract}
ABSTRAK
Penelitian ini dilaksanakan pada bulan Januari - Februari 2015 bertempat di Kabupaten Biak Numfor dengan menggunakan metode survey untuk mengetahui komposisi serta nilai-nilai Kerapatan (K), Kerapatan Relatif (KR), Frekuensi (F), Frekuensi Relatif (FR), Dominasi (D), Dominasi Relatif (DR), dan Indeks Nilai Penting (INP) dari setiap jenis vegetasi mangrove. Hasil penelitian menunjukan bahwa struktur komunitas hutan mangrove di pesisir Kabupaten Biak Numfor terdiri dari 8 jenis yang terbagi dalam 5 family dengan kerapatan jenis tertinggi pada jenis Rhizophora apiculeta dan Senoratia alba sedangkan frekuensi kehadiran umumnya adalah Bruguiera gymnorrhiza dan Senoratia alba. Hasil lain menunjukan bahwa kondisi hutan mangrove di pesisir Timur Kabupaten Biak Numfor telah mengalami penurunan akibat pemanfaatan yang berlebihan.
\end{abstract}

Kata Kunci: Mangrove, Kabupaten Biak Numfor

\section{PENDAHULUAN}

\subsection{Latar Belakang}

Secara administratif, Kabupaten Biak Numfor termasuk ke dalam wilayah Propinsi Papua terdiri dari 12 Kecamatan dan secara geografis terletak pada posisi 1340 o $55^{\prime}$ - 1360 BT dan 0o 55' - 10 27' LS. Kabupaten ini berbatasan di sebelah utara dengan Samudera Pasifik dan Kabupaten Supiori, di sebelah Selatan berbatasan dengan Selat Yapen, di sebelah barat berhadapan dengan Kabupaten Manokwari dan Sebelah Timur berbatasan dengan Samudera Pasifik dan Kabupaten Supiori. Kabupaten Biak Numfor merupakan salah satu kabupaten kepulauan di Propinsi Papua. Kabupaten ini terdiri dari kurang lebih 40 pulau-pulau kecil yang dikelilingi oleh ekosistim terumbu karang, Padang lamun dan Hutan mangrove.

Kehidupan masyarakat yang mendiami pulau-pulau kecil tersebut memiliki ketergantungan yang sangat tinggi terhadap ketersediaan sumberdaya pesisir dan laut. dengan demikian terdapat keterkaitan langsung antara masyarakat dengan upaya pengelolaan

wilayah pesisir yang mengandung potensi sumberdaya dan keanekaragaman hayati yang beragam. Dalam pengelolaan wilayah pesisir, ditemui suatu kenyataan bahwa ancaman pengrusakan sumberdaya yang tinggi sementara terjadi di daerah ini dan tidak terkeculali di wilayah Timur Kabupaten Biak Numfor.

Era pembangunan yang semakin pesat dengan mengembangkan ekonomi nasional, menempatkan wilayah pesisir dan pantai pada posisi yang penting. Pusat pusat industri, pusat pembangkit listrik, lokasi rekreasi, pemukiman, pertambakan, dan sarana perhubungan lainya yang banyak dibangun di wilayah pesisir merupakan dilema (Purnobasuki, 2005).

Walters et al (2008) menyatakan bahwa hutan mangrove di sepanjang pesisir pantai dan sungai secara umum menyediakan habitat bagi berbagai jenis ikan. Hutan mangrove sebagai salah satu lahan basah di daerah tropis dengan akses yang mudah serta kegunaan komponen biodiversitas dan lahan yang tinggi telah menjadikan sumberdaya tersebut sebagai sumberdaya tropis yang kelestariannya akan 
terancam (Valiela et al 2001) dan menjadi salah satu pusat dari isu lingkungan global. Konversi hutan mangrove terus meningkat untuk dijadikan lahan pertanian atau tambak ikan/udang, sehingga menyebabkan penurunan produktivitas ekosistem tersebut (Dave, 2006).

(Dahuri dkk 2004). Masalah yang biasa terjadi dalam pemanfaatan sumberdaya pesisir dan laut berkaitan erat dengan perilaku masyarakat pengguna sumberdaya tersebut. Perlakuan terhadap sumberdaya ini hampir selalu dilandasi oleh kerangka pikir open akses, yang menyebabkan tidak seimbangnya laju pemanfaatan dan laju pemulihan sumberdaya tersebut. Dengan demikian, dalam konteks pengelolaan sumberdaya pesisir yang berkelanjutan diperlukan suatu upaya terpadu yang mempertimbangkan kelestarian sumberdaya bagi tabungan di masa datang.

Berdasarkan pemahaman yang ada, maka pengelolaan sumberdaya pesisir harus dilakukan secara baik sehingga keanekaragaman hayati dapat selalu terjaga dan lestari. Guna menyusun suatu strategi konservasi ekosistem pesisir sudah tentu dibutuhkan berbagai data dan informasi tentang potensi dan permasalahan dalam pengelolaan wilayah serta kondisi sosial ekonomi masyarakat yang mendiami ekosistem tersebut.
1.2. Tujuan Penelitian

Penelitian ini bertujuan untuk mengetahui nilai-nilai Kerapatan (K), Kerapatan Relatif (KR), Frekuensi (F), Frekuensi Relatif (FR), Dominasi (D), Dominasi Relatif (DR), dan Indeks Nilai Penting (INP) dari setiap jenis pada masingmasing vegetasi, serta komposisi jenis mangrove di pesisir timur Kabupaten Biak Numfor.

\section{METODE PENELITIAN}

\subsection{Tempat dan waktu penelitian}

Kegiatan inventarisasi ini dilakukan di wilayah pesisir Timur Kabupaten Biak Numfor (Gambar 1). Waktu penelitian dilaksanakan pada bulan Januari sampai bulan Februari 2015.

\subsection{Prosedur kerja}

Prosedur kerja meliputi penentuan stasiun penelitian dengan metode purpossive random sampling yang didahului dengan survei lapangan dan pencitraan melalui aplikasi Google earth. Setelah ditentukan tiga stasiun penelitian berdasarkan ketebalan vegetasi dan bentang geografis, plot transek dibuat di setiap stasiun dengan ukuran $2 \times 2$ meter untuk semai, $5 \times 5$ meter untuk pancang dan $10 \times 10$ meter untuk pohon. Beberapa data yang diambil dalam penelitian ini antara lain : jenis mangrove, jumlah tegakan mangrove, diameter batang setinggi dada dan beberapa data parameter fisik dan kimia sebagai pelengkap.

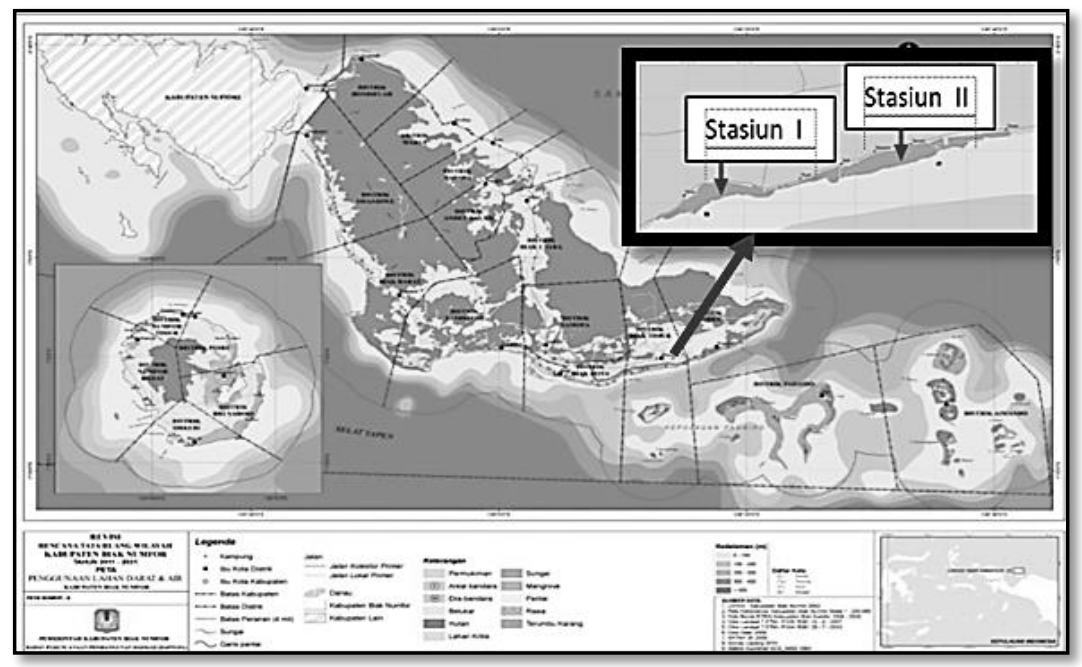

Gambar 1. Peta lokasi Penelitian 


\subsection{Analisis data}

Untuk mengetahui gambaran komposisi jenis, maka data yang diperoleh diolah dan dianalisa dengan cara menghitung nilai-nilai Kerapatan (K), Kerapatan Relatif (KR), Frekuensi (F), Frekuensi Relatif (FR), Dominasi (D), Dominasi Relatif (DR), dan Indeks Nilai Penting (INP) dari setiap jenis pada masing-masing vegetasi Data mangrove yang diperoleh dianalisis dengan persamaan yang diusulkan oleh Cox (1967) dan meliputi :

$$
\begin{aligned}
& \text { Kerapatan relatif }= \\
& \frac{\text { Jumlah individu tiap jenis }}{\text { Jumlah keseluruhan individu }} \times 100 \% \\
& \text { Frekuensi relatif }= \\
& \frac{\text { Frekuensi kehadiran tiap jenis }}{\text { Frekuensi dari semua jenis }} \times 100 \% \\
& \text { Dominasi relatif (DR) }= \\
& \frac{\text { Total Basal Area tiap jenis }}{\text { Total Basal Area semua jenis }} \times 100 \%
\end{aligned}
$$

Nilai Penting (NP) $=$

kerapatan relatif + Frekuensi relatif + DR

Nilai penting (NP) digunakan untuk mengetahui keadaan penguasaan spesies dalam komunitas di habitatnya. NP menggambarkan kedudukan ekologis suatu jenis di dalam komunitas. Semakin tinggi NP suatu spesies maka semakin besar peran spesies tersebut dalam komunitasnya.

\section{HASIL DAN PEMBAHASAN}

\subsection{Luasan Ekosistem Mangrove}

Ekosistem Mangrove di wilayah pesisir Biak Timur memiliki luas secara keseluruhan adalah 98,08 Ha dan tersebar pada 2 (dua) stasiun penelitian. Luasan ekosistem mangrove saat ini bila dibandingkan dengan Tahun 2002 terjadi penurunan yang cukup signifikan yakni mencapai 15,30 Ha dari total keseluruhan sesuai yang dilaporkan adalah seluas 115,38 Ha. Berdasarkan hasil inventarisasi dilapangan, tercatat pada wilayah pesisir Biak Timur terdapat 8 jenis yang digolongkan dalam 5 famili. Untuk lebih jelasnya mengenai komposisi jenis ekosistem mangrove di wilayah pesisir Biak Timur di sajikan pada tabel 1.
Tabel 1. Komposisi Jenis Mangrove di wilayah pesisir Biak Timur

\begin{tabular}{clr}
\hline \multicolumn{1}{c}{ Family } & \multicolumn{2}{c}{ Spesies } \\
\hline \multirow{2}{*}{ Rhizophoraceae } & $\begin{array}{l}\text { Rhizophora stylosa, } \\
\text { apiculata, Bruguiera }\end{array}$ & $\begin{array}{r}\text { Rymnopora } \\
\text { Brugiera cylindrica }\end{array}$ \\
Soneratiaceae & Sonneratia alba \\
Myrsinaceae & Aegiceras corniculatum \\
Arecaceae & Nypa fruticans \\
Meliaceae & Xylocarpus granatum \\
\hline
\end{tabular}

Dari hasil inventarisasi yang dilakukan, maka dapat dilihat distribusi mangrove di wilayah pesisir Biak Timur sebagai berikut: di bagian terluar yang berbatasan dengan komunitas mangrove terdapat jenis Sonneratia alba, kemudian terdapat jenis Rhizophora stylosa, Rhyzopora apiculata. Selanjutnya dibagian belakang, terdapat Aegiceras corniculatum, Bruguiera gymnorrhiza, Brugiera cylindrica, Bruguiera parviflora, dan Xylocarpus granatum. Kemudian dibagian belakang yang berbatasan dengan daratan terdapat jenis Nypa fruticans. Sebaran ekosistem mangrove pada dua

\begin{tabular}{|c|c|c|c|}
\hline \multirow{2}{*}{ No } & \multirow{2}{*}{ Nama Jenis } & \multicolumn{2}{|c|}{ Stasiun } \\
\hline & & I & II \\
\hline 1 & Rhizophora stylosa & $\sqrt{ }$ & $\sqrt{ }$ \\
\hline 2 & Rhyzopora apiculata & $\sqrt{ }$ & $\sqrt{ }$ \\
\hline 3 & Bruguiera gymnorrhiza & $\sqrt{ }$ & $\sqrt{ }$ \\
\hline 4 & Brugiera cylindrica & $\sqrt{ }$ & $\sqrt{ }$ \\
\hline 5 & Sonneratia alba & $\sqrt{ }$ & $\sqrt{ }$ \\
\hline 6 & Aegiceras corniculatum & & $\sqrt{ }$ \\
\hline 7 & Nypa fruticans & $\sqrt{ }$ & \\
\hline 8 & Xylocarpus granatum & $\sqrt{ }$ & \\
\hline & Jumlah Jenis & 7 & 6 \\
\hline
\end{tabular}
stasiun terdapat perbedaan, dimana ada pada stasiun I terdapat 7 jenis dan untuk stasiun 2 (dua) hanya terdapat 6 jenis. Untuk lebih jelas disajikan pada Tabel berikut.

Tabel 2. Distribusi Mangrove di Stasiun I dan II

Berdasarkan Tabel 2, terlihat bahwa dari 8 jenis mangrove yang ada di wilayah pesisir timur Kabupaten Biak Numfor, terdapat 1 jenis yang tidak ditemukan di Stasiun I (satu) yakni Aegiceras corniculatum. Sedangkan di Stasiun II terdapat 2 (dua) jenis mangrove yang tidak ditemukan yakni jenis Xylocarpus granatum. 


\subsection{Kerapatan Jenis}

Dari hasil analisis data yang dilakukan, untuk Stasiun I diperoleh nilai kerapatan tertinggi untuk kategori pohon yaitu Rhyzopora apiculata dengan nilai 526,32 ind/ha $(53,47 \%)$, kategori semai dan sapihan jenis Rhyzopora apiculata juga memiliki nilai kerapatan tertinggi yakni 26346,15 ind/ha $(86,50 \%)$. Sedangkan untuk nilai kerapatan terendah untuk kategori pohon yaitu jenis Sonneratia alba dengan nilai 31,58 ind/ha $(3,21 \%)$ dan untuk kategori semai dan sapihan jenis ini juga memiliki nilai kerapatan rendah yakni 384,62 ind/ha (1\%). Jenis Rhyzopora apiculata memiliki nilai kerapatan tertinggi, hal ini disebabkan karena spesies ini cenderung lebih toleran terhadap substrat berlumpur.

Selanjutnya untuk Stasiun II (dua) diperoleh nilai kerapatan tertinggi untuk kategori pohon yaitu Sonneratia alba dengan nilai 483,33 ind/ha $(39,65 \%)$ diikuti oleh jenis Rhyzopora apiculata dengan nilai 416,67 ind/ha (34,18\%), kategori anakan/semai jenis Rhyzopora apiculata juga memiliki nilai kerapatan tertinggi yakni 533,33 ind/ha $(64,65 \%)$. Sedangkan untuk nilai kerapatan terendah untuk kategori pohon yaitu jenis Aegiceras corniculatum dengan nilai 88,89 ind/ha $(7,29 \%)$ dan untuk kategori anakan/semai jenis ini Sonneratia alba memiliki nilai kerapatan yang rendah yakni 277,78 ind/ha $(0,33 \%)$. Untuk kategori pohon untuk jenis Sonneratia alba memiliki nilai tertinggi. Secara keseluruhan, rata-rata kerapatan seluruh jenis mangrove di pesisir Stasiun II (dua) yaitu: 304,765 phn/Ha. Sedangkan untuk Stasiun I (satu) memliki rata-rata kerapatan 140,61 phn/Ha. Dengan demikian, sesuai dengan Keputusan Menteri Lingkungan Hidup No. 201 Tahun 2004 tentang kriteria baku kerusakan mangrove, maka wilayah pesisir Timur Kabupaten Biak Numfor (Stasiun I dan StasiunII) memiliki mangrove dengan kerapatan jarang $(<1000 \mathrm{phn} / \mathrm{Ha})$.

\subsection{Frekuensi Kehadiran}

Berdasarkan hasil analisis, nilai frekuensi kehadiran tertinggi di Stasiun I untuk kategori pohon dan tiang dimiliki oleh jenis Bruguiera gymnorrhiza, dengan nilai frekuensi kehadiran dan frekuensi kehadiran relatif untuk setiap kategori berturut-turut adalah; 0,84 dan 41,02\% untuk pohon, 0,54 dan 63,83\% untuk anakan. Sedangkan untuk Stasiun II frekuensi kehadiran tertinggi untuk kategori pohon dan tiang dimiliki oleh jenis Sonneratia alba dengan nilai 0,67 dan $38,50 \%$ dan untuk anakan/semai dimiliki oleh jenis Rhyzopora apiculata dengan nilai 0,56 dan $71 \%$.

Frekuensi kehadiran di Stasiun I (satu) dari jenis Bruguiera gymnorrhiza untuk kategori pohon dan anakan lebih tinggi dari jenis-jenis yang lain dikarenakan kondisi substrat lumpur berpasir yang hampir merata di seluruh bagian perairan Stasiun I dan ini merupakan substrat yang cocok bagi pertumbuhan Bruguiera gymnorrhiza sehingga spesies ini dapat ditemukan hampir disepanjang pantai. Sedangkan untuk Stasiun II, frekuensi kehadiran Sonneratia alba untuk kategori pohon dan tiang karena sepanjang pesisir pantai memiliki substrat lumpur, berpasir dan berkarang sihingga jenis ini sangat cocok untuk pertumbuhan spesies ini.

\subsection{Nilai Penting}

Berdasarkan perhitungan nilai penting yang dilakukan, spesies Bruguiera gymnorrhiza memiliki nilai nilai tertinggi dengan $77,74 \%$ kemudian terendah adalah jenis Aegiceras corniculatum $17,07 \%$. Pada perhitungan nilai penting spesies Bruguiera gymnorrhiza memiliki nilai persen penutupan dan frekuensi kehadiran yang tinggi, hal ini disebabkan oleh spesies ini ditemukan pada semua transek pengamatan. Spesies Aegiceras corniculatum memiliki nilai persen penutupan dan frekuensi kehadiran yang rendah, hal ini disebabkan oleh spesies ini merupakan yang paling sedikit ditemukan pada transek pengamatan.

\subsection{Bentuk-bentuk Pemanfaatan Ekosistem Mangrove \\ Ekosistem Mangrove dapat dimanfaatkan} untuk berbagai keperluan. Beberapa Kampung di wilayah pesisir Biak Timur hingga saat ini belum memiliki peraturan serta sangsi yang baku tentang pengelolaan ekosistem mangrove. Pemanfaatan hutan mangrove oleh masyarakat 
setempat. Aktifitas-aktifitas tersebut diuraikan secara singkat pada Tabel 3.

Tabel 3. Aktifitas Pemanfaatan, Dampak Dan Lokasi Ekosistem Mangrove

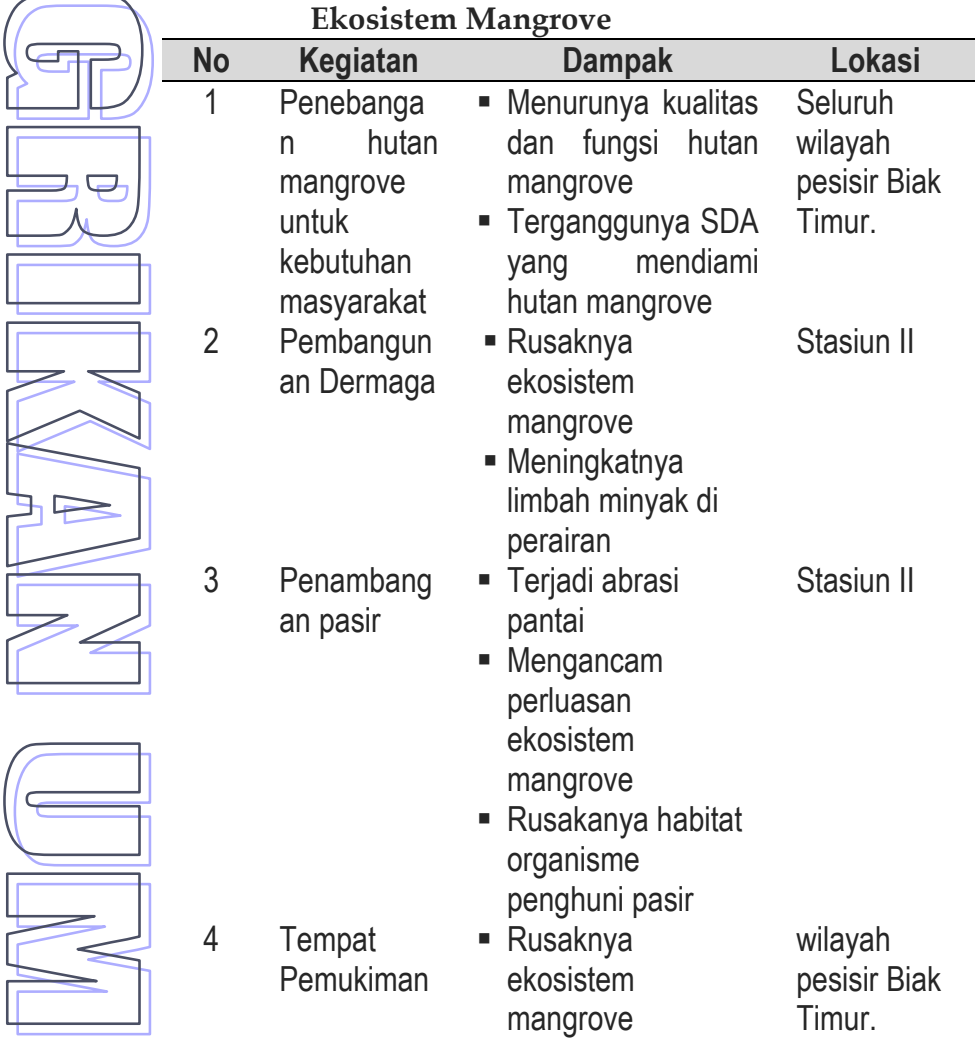

5 Budidaya Perikanan

- Hilangnya habitat organisme laut

- Peningkatan jumlah sampah rumahtangga

- Pengalihan fungsi Stasiun I lahan

\section{PENUTUP}

- Struktur komunitas hutan mangrove di pesisir timur Kabupaten Biak Numfor terdiri dari 8 (delapan) jenis yang termasuk dalam 5 (lima) family yaitu didominasi oleh family Rhizophoraceae,Somneratiaceae, Myrsinaceae, Arecaceae, Meliaceae.

- Kerapatan jenis dengan nilai tertinggi pada mangrove jenis Rhizopora apiculata, dan Soneratia alba, sedangkan Frekuensi kehadiran umumnya adalah Bruguiera gymnorrhiza dan soneratia alba

- Kondisi Hutan mangrove di pesisir timur Kabupaten Biak Numfor telah mengalami penurunan akibat pemanfaatan yang berlebihan.

\section{DAFTAR PUSTAKA}

Purnomo, E. 2000. Laju Penghancuran Serasah Rhizophora mucronata dan Keanekaragaman Jenis Biota Decomposer Makro di Perairan Pantai Utara Surabaya. Fakultas Matematika dan Ilmu Pengetahuan Alam Universitas Airlangga. Surabaya.

Yosmina Tapilatu dan Daniel Pelasula . 2012 . BIOTA PENEMPEL YANG BERASOSIASI DENGAN MANGROVE DI TELUK AMBON BAGIAN DALAM. Jurnal Ilmu dan Teknologi Kelautan Tropis, Vol. 4, No. 2, Hlm. 267-279, Desember 2012

Farley.J.,Batker .d, Torre d.1.I., Hudspeth.T . 2009. Conserving Mangrove Ecosystems in the Philippines:Transcending Disciplinary and Institutional Borders. Springer Science. Environemtal Management.

Dahuri, R et al.1996.Pengelolaan Sumber Daya Wilayah Pesisir dan Lautan Secara Terpadu . Pradnya Paramita: Jakarta

Dave, R.2006. Mangrove ecosystem of south, west Madagascar: an ecological, human impact, and subsistence value assessment. Tropical Res Bulletin .

Walters, BB., P. Ronnback, JM. Kovacs,B. Crona, S.A. Hussain, R. Badola,J.H. Primavera, E. Barbier, danF.Dahdouh-Guebas, 2008.Ethnobiology,Socio Economic and Managemen of Mangrove Forests:a review. Aquatic Botany

Valiela, I., J.L. Bowen, dan JK. York. 2001.Mangrove Forest: One of the World's Threatened Major Tropical Environments.Bioscience

Cox, G.W. 1967.Laboratory manual of general ecology. M.W.C. Brown Company. Minneapolis. 